\title{
Effective Professors: An Insight into their Philosophy and Practice
}

\author{
Stephen Joseph, PhD \\ Centre for Education Programmes, \\ University of Trinidad and Tobago
}

\begin{abstract}
This qualitative study investigated the philosophy and practice of effective professors in the Trinidad and Tobago education system. A purposive sampling method was employed, utilizing standardized, open-ended student interviews as the data collection method for the study. Data analysis consisted of examining, categorizing, and tabulating the evidence to address two research questions of the study. Three themes emerged from the study, namely, getting to know students; teacher as life-long learner; and teacher as role model. Findings of the study revealed that most of the participants believe that getting to know students is an important element in their teaching, while others embrace the idea of life-long learning as an essential requirement for a successful practice. Some professors in the study hold a somewhat idealist philosophy and focus on modelling positive behaviours for students to emulate. While the results of this study cannot be generalized to the larger population of teachers in Trinidad and Tobago, the study is important because it provides an insight into the different philosophic positions of professors. It also introduces the conversation of how effective teachers conduct their practice in the context of the Trinidad and Tobago education system.
\end{abstract}

Keywords: Effective teachers and professors, philosophy and practice

\section{INTRODUCTION}

Whether consciously or not, all teachers bring to the classroom their own philosophical beliefs and perspectives that influence their teaching and shape the way they interact with students. Research findings support the connection between philosophic positions and educational practice (Conti, 1985, 2007; Coppola, 2002; East, 2013). Giorgi and Roberts (2012) agree that an effective professor has a clearly defined philosophy that outlines his core values as a teacher.

Rossetti and Fox (2009) found four main themes in their search for factors related to successful teaching by outstanding professors. The first theme deals with the notion of presence which refers to the professor's interaction or relationship with students based on trust, respect, and caring. Promotion of learning is the second theme which suggests that professors are dedicated and committed to their work. The idea of teachers as learners was the third theme which suggests that professors continue to engage in life-long learning in order to keep their practice current. The final theme relates to a teaching style marked by enthusiasm and a love for their subject matter.

In a more recent study, Carraway and Burris (2017) explored common philosophical beliefs about teaching and learning in effective professors operating at a tertiary-level institution. The six emerging themes included: engaging students in learning; maintaining student interest; getting to know students; assessing student knowledge; setting high expectations for students and participating in professional development activities. 
Research findings on student conceptions of the most effective professor fall into three major categories: (1) knowledge of the subject taught (2) personal qualities (3) knowledge of teaching and learning (Arnon \& Reichel, 2007; Crawford \& Bradshaw, 1968; Desai \& Jones, 2001; Douna, Kyridis, Zagkos, Ziontaki, \& Pandis, 2015; Epting, Zinn, Buskist \& Buskist, 2004; Hill, Lomas \& MacGregor, 2003; Korte, Lavin \& Davies, 2013; Obermiller, Ruppert, \& Atwood, 2012; Paswan \& Young, 2002; Slate, La Prairie, Schulte, \& Onwuegbuzie, 2011; Swanson, Frankel \& Sagan, 2005; Witcher, Onwuegbuzie \& Minor, 2001).

In a study on teachers who attract or repel, participants listed professionalism; dedication to teaching; preparedness for class; strong ethical values; and caring as the most important characteristics they expect effective professors to possess in the teaching/learning context (Joseph, 2016). The study concluded that understanding students' expectations of their professors is important for establishing a good professor-student type of relationship that inspires student success. This current study utilizes students' conceptions of effective professors as a launching pad to gain further insights into the philosophy that guides their practice.

\section{THEORETICAL FRAMEWORK}

The Theoretical framework for this study draws on the philosophical traditions of idealism, realism and pragmatism purported by philosophers such as Socrates, Plato, Aristotle, and Dewey. Persons who identify with the idealist tradition see the teacher's role as one of passing on knowledge of reality and setting an example of what is considered to be the ethical ideal. Realist teachers want to develop the thinking abilities of students who must make judgements based on careful consideration of evidence. Those professors who embrace the philosophy of pragmatism believe that truth is a concept that evolves over time and that reality is not fixed, but it is in a constant state of flux as one's experience broadens. Pragmatist teachers, therefore, want to provide learning experiences for students that will develop and deepen their problemsolving skills (Armstrong, 2003). The study is also built on postmodern epistemology influenced by early proponents as Kierkegaard, Nietzsche, Husserl and Heidegger. Generally speaking, postmodern philosophy rejects many positions associated with the perspectives of idealism, realism, and pragmatism; and professors who subscribe to postmodern philosophy stress the importance of skepticism, open-ended conclusions and on-going dialogue about significant issues (Beck, 1993).

\section{PURPOSE OF THE STUDY}

The purpose of this study was to investigate the philosophy and practice of effective professors operating in the education system of Trinidad and Tobago. Two research questions served to focus this investigation:

1. How do effective professors describe the philosophy that guides their practice?

2. How do effective professors conduct their practice as professionals?

\section{Description of the participants}

\section{METHODOLOGY}

A purposive sampling method was used to obtain information from 35 teachers who operate in the Trinidad and Tobago education system. Thirty-five university students were asked to interview one professor whom they believed to be highly effective in the teaching and learning process. Table 1 provides a summary of students' reasons for selecting the participants of the study. 
Table 1. Students' Reasons for Selecting Participants of the Study

\begin{tabular}{|l|l|}
\hline $\begin{array}{l}\text { Number of } \\
\text { Students }\end{array}$ & \multicolumn{1}{c|}{ Reasons for Selection } \\
\hline 7 & Willingness to go the extra distance to assist students; hard-working and dedicated \\
\hline 6 & $\begin{array}{l}\text { Professionally attired; good role model; strong pedagogical skills; strong content } \\
\text { knowledge }\end{array}$ \\
\hline 4 & Student-centred; respect for students; nurturing and caring \\
\hline 7 & $\begin{array}{l}\text { Compassionate; reliable and approachable; fairness of treatment; patient and } \\
\text { understanding }\end{array}$ \\
\hline 8 & Passion for the job; enthusiastic about teaching; good relationship with students \\
\hline 2 & Innovative and creative teaching style; ability to create an effective learning environment \\
\hline 1 & Strong moral and spiritual values \\
\hline
\end{tabular}

\section{Design}

Qualitative interviews were conducted utilizing two standardized, open-ended questions for all 35 participants of the study. These questions were designed to gain insight into the philosophy that guides the practice of teachers in the Trinidad and Tobago education system.

\section{Procedures and Data Analysis}

A qualitative semi-structured interviewing technique was used as a data collection method for this study. This form of data collection is particularly useful in facilitating the type of flexibility required for discussing the experiences and perspectives of the participants (Crano \& Brewer, 2002; Sarantakos, 2005). A standard protocol was developed for the 35 interviews which were taped and transcribed verbatim. Each interview lasted approximately 30 minutes, following which participants were given the opportunity to verify information generated during the interview sessions. Undergraduate students who conducted the interviews were trained in asking probing questions to obtain additional information when necessary. Lincoln and Guba (1985) confirm that member checking or respondent validation is a necessary procedure to establish validity for a qualitative study.

Data analysis for this study consisted of examining, categorizing, and tabulating the evidence to address the two research questions of the study (Yin, 2003). The following three themes emerged from information provided by participants of the study:

1. Getting to know students

2. Teacher as lifelong learner

3. Teacher as role model

\section{Getting to know students}

\section{RESULTS}

Most of the participants of the study believe that getting to know students is an important element in their teaching. They want to make students feel safe and comfortable while performing at their potential level in an environment that fosters creativity and growth. In general, professors see themselves as facilitators of learning and are interested in finding out how students learn in order to cater to their varying interests, readiness, and learning profiles. One veteran teacher with 30 years' experience explains:

My philosophy is that each pupil has the potential to bring something unique and special ... and I try my best to develop their potential by believing in them as individuals. I accept their different learning styles and abilities ... and use various methods to teach ... I believe that although I have been teaching for a long period, there is much to learn every day. I do not give up on my pupils ... I teach and re-teach when necessary. 
A novice teacher with five years' teaching experience also shares a similar philosophy: He says: I teach to meet the needs of all my students. I am always willing to adjust content to fit the needs of my students and I accommodate diversity. I never have two of the same classes ... I always have to make adjustments because every single student is different; so as a teacher you can never be too rigid.

This veteran teacher with 37 years' experience speaks of a philosophy of respect. She puts it this way:

Once you treat students respectfully, they will treat you with the same respect. I maintain a positive teacher/student relationship ... I set standards for the class and provide support for students ... I treat students with high regard.

One professor echoes similar sentiments when she asserts that:

Every child must be respected as an individual despite religion, race, ethnicity, and socio-economic status.

She suggests that a good way to know students is to:

Create a profile of each student with information relating to their background, learning styles, and home environment.

She says:

I always keep in contact with parents ... I am always reflecting, I believe sometimes too often.

One teacher sums up the discussion this way:

I believe that if I could help children bring out the best in themselves, I would have succeeded as a teacher.

\section{Teacher as lifelong learner}

Some participants of the study embrace the idea of life-long learning as an important requirement for successful practice as a teacher. One practitioner says:

of course as a teacher you never stop learning ... if you are dedicated, you will always strive to improve your practice.

A veteran teacher with over 30 years' experience also highlights the importance of life-long learning. Echoing the sentiments of other participants she says:

I always seek ways to improve myself ... I often attend workshops provided by the Ministry of Education and I read, conduct research and educate myself on new technology in order to keep up with the rapidly changing world.

\section{Teacher as role model}

Embracing an idealist philosophic position, many participants see their role as setting high ethical standards and modelling positive behaviours for students to emulate. When asked about professional conduct, this is what one participant had to say:

My teaching is not limited to academics. I try to display proper habits of dress, regularity and punctuality - characteristics which pupils will imitate.

Echoing similar sentiments, one teacher puts it this way:

I model in my own teaching what I expect of my students such as punctuality ... and I place great emphasis on respect and manners. 
One professor says:

I believe that a teacher is the most powerful role model and so I treat everyone with dignity and respect. And I expect the same in return.

Another participant believes that modelling ethical behaviour goes beyond the classroom. She cautions:

You are looked upon as a teacher even when you are out of the classroom ... The way you dress, speak and carry about yourself outside the classroom should be in a manner that befits a teacher.

\section{DISCUSSION}

Three major themes emerged from the information provided by participants of this study. The first theme focussed on the importance of getting to know students in the classroom. Results of the study support findings of Carraway and Burris (2017) who identified getting to know students as one of the six common philosophical beliefs of effective professors operating in a tertiary-level teaching/learning environment. In this current study, the majority of professors believe that getting to know students is an important step in understanding how they learn in order to cater to their varying needs. Participants made reference to adjusting content and reteaching concepts when necessary to facilitate optimal learning among students. This suggests that effective teachers are interested in differentiating instruction in response to student readiness, interest, and learning profiles (Tomlinson, 2014; Tomlinson \& Imbeau, 2010). One participant in the study highlighted the importance of creating student profiles to assist in the process of getting to know them better. This practice is closely linked to what one veteran teacher described as a philosophy of respect, which augurs well for a positive teacher/student relationship. Rossetti and Fox (2009) refer to such a relationship as presence based on trust, respect and caring. It is interesting to note that the university students who conducted interviews with participants of this study also identified qualities of caring, respect, and good relationship with students as distinguishing marks of an effective professor.

The second theme in the study dealt with teachers as life-long learners who must constantly find ways to improve themselves in order to remain at the cutting edge of their practice. Findings of the study revealed that veteran teachers with over 30 years' experience demonstrate the importance of life-long learning by attending workshops, conducting research, and keeping abreast with new technologies in an effort to cope with the challenges of a rapidly changing world. Findings from this study also mirror results of other studies conducted by Rossetti and Fox (2009) as well as Carraway and Burris (2017), who found that effective professors participate in professional development activities and generally embrace life-long learning as a personal philosophy.

The final theme highlighted the effective professor as a role model for students to emulate. Participants of the study are very conscious about the way they dress, speak and conduct themselves both inside and outside the classroom. This notion of the teacher as role model has strong linkages to idealist philosophy which promotes the idea of the teacher as an exemplar who is responsible for passing on the virtues of the past by being an example of the ethical ideal. This contrasts sharply with the philosophy of only a few teachers in the study who believe that there is no ideal, since truth evolves over time and reality is constantly changing. These teachers believe that students should develop a mindset of searching to uncover evidence for themselves as they seek to solve problems that exist in the real world. Only two participants referred to themselves as pragmatists, and one mathematics teacher veered toward realism as a philosophic position. While some participants spoke about the importance 
of students going in search of their own knowledge, no one explicitly identified with postmodern epistemology upon which constructivism is built.

\section{CONCLUDING COMMENTS}

It is well-known that educational practices are built on philosophic beliefs. These beliefs influence how teachers perceive their role as educators and what teaching methodologies they adopt in the classroom. For example, professors who adopt an idealist philosophy are more likely to see themselves as role models and purveyors of truth as opposed to those who embrace postmodern epistemology. Such teachers want their students to construct their own meanings and provide them with opportunities to engage rich and diverse perspectives through open-ended conclusions and on-going dialogue about important issues.

The literature has identified common philosophical beliefs that guide the practice of effective teachers. These include the promotion of life-long learning, getting to know students, and other personal qualities such as caring and respect for students. Although this study corroborates the findings of earlier studies, it also highlights a strong idealist philosophic position held by the majority of participants who see themselves as role models for students. While the results of this study cannot be generalized to the larger population of teachers in Trinidad and Tobago, the philosophic positions of these 35 participants provide a launching pad for further conversation about the philosophy that guides the practice of those considered to be effective teachers in the education system.

\section{RECOMMENDATIONS}

- There is need for further investigation into the different philosophies that guide the practice of effective teachers and professors in the education system. This can be done using a mixed-methods approach with a larger sample size.

- Studies can be conducted also to determine the extent to which an idealist philosophic position is shared by effective professors within the education sector.

\section{References}

Armstrong, D. (2003). Curriculum Today. Upper Saddle River, New Jersey: Merrill Prentice Hall.

Arnon, S. \& Reichel, N. (2007). "Who is the ideal teacher? Am I? Similarities and differences in perception of students of education regarding the qualities of a good teacher and their own qualities as teachers." Teachers and Teaching: theory and practice, 13(5), 441-464. http://dx.org/10.1080/13540600701561653

Beck, Clive (1993). Postmodernism, pedagogy and philosophy of education. Philosophy of Education, 27: 1-13.

Carraway, C. \& Burris, S. (2017). Common themes emerged from teaching philosophies and methods of effective postsecondary teachers. North American Colleges and Teachers of Agriculture (NACTA) Journal, 61(1), 27-32.

Conti, G. J. (1985). The relationship between teaching style and adult student learning. Adult Education Quarterly, 35(4), 220-228.

Conti, G. J. (2007). Identifying your educational philosophy: Development of the philosophies held by instructors of lifelong-learners (PHIL). Journal of Adult Education, 36(1), 19-35.

Coppola, B. (2002). Writing a statement of teaching philosophy. Journal of College Science Teaching, 31(7), 448453.

Crano, W. D., \& Brewer, M. B. (2002). Principles and methods of social research (2 ${ }^{\text {nd }}$ ed.). Mahwah, NJ: Lawrence Erlbaum Associates.

Crawford, P. L., \& Bradshaw, H. L. (1968). Perception of characteristics of effective university teachers: A scaling analysis. Educational and Psychological Measurement, 28: 1079-85.

Desai, S., Damewood, E., \& Jones, R. (2001). Be a good teacher and be seen as a good teacher. Journal of Marketing Education, 23(2), 136-143. 
Douna, P., Kyridis, A., Zagkos, C., Ziontaki, Z., \& Pandis, P. (2015). The ideal university teacher according to the views of Greek students. International Journal of Higher Education, 4(20, 145-158.

East, W. T., Jr. (2013). Educational philosophies and teaching styles of Alabama Cooperative Extension system agents. Retrieved from http://etd.auburn.edu/handle/10415/3738

Epting, L. K., Zinn, T. E., Buskist, C., \& Buskist, W. (2004). Students perspectives on the distinction between ideal and typical teachers. Teaching of Psychology, 31(3), 181-183.

Giorgi, A. \& Roberts, G. (2012). Exploring the teaching beliefs of excellent undergraduate professors. North American Colleges and Teachers of Agriculture (NACTA) Journal, 56(1), 60-66.

Hill, Y., Lomas, L.L., \& MacGregor, J. (2003). Students' perceptions of quality in higher education. Quality Assurance in Education, 11(1), 15-20.

Joseph, S. (2016). Teachers who attract or repel: A glimpse at student expectations of their tertiary-level teachers. International Journal of Learning, Teaching and Educational Research, 15(2), 21-31.

Korte, L., Lavin, A., \& Davies, T. (2013). An investigation into good teaching traits. Journal of Learning in Higher Education, 9(1), 141-150.

Lincoln, Y. \& Guba, E. (1985). Naturalistic inquiry. Newbury Park, CA: Sage Publications.

Obermiller, C., Ruppert, B., \& Atwood, A. (2012). Instructor credibility across disciplines: Identifying students' differentiated expectations of instructor behaviours. Business Communication Quarterly, 75(2), 153-165. DOI: $10.1177 / 1080569911434826$

Paswan, A.K., \& Young, J.A. (2002). Student evaluation of instructor: A nomological investigation using structural equation modeling. Journal of Marketing Education, 24(3), 193-202

Rossetti, J \& Fox, P. (2009). Factors related to successful teaching by outstanding professors: An interpretive study. Journal of Nursing Education, 48(1), 11-16. DOI 10.3928/01484834-20090101-09

Slate, J., La prairie, N., Schulte, D., Onwuegbuzie, A. J. (2011). Views of effective college faculty: A mixed analysis. Assessment \& Evaluation in Higher Education, 36(3), 331-346.

Sarantakos, S. (2005). Social research. Hampshire, Palgrave Macmillan.

Swanson, S.R., \& Frankel, R. (2002). A view from the podium: Classroom successes, failures, and recovery strategies. Marketing Education Review, 12(2), 25-35.

Tomlinson, C. A. (2014). The differentiated classroom. Alexandria, Virginia: ASCD.

Tomlinson, C. A., \& Imbeau, M. B. (2010). Leading and managing a differentiated classroom. Alexandria, Virginia: ASCD.

Witcher, A. E., Onwuegbuzie, A. J., \& Minor, L. (2001). Characteristics of effective teachers: Perceptions of preservice teachers. Research in the Schools, 8(2), 45-57.

Yin, R. K. (2003). Case study research: Design and methods (3 ${ }^{\text {rd }}$ ed.). Thousand Oaks, CA: Sage. 